\title{
Criteria for the Formation and Dynamics of Sport Land through Urban Non-Place (with a Focus on the Experiences of Mashhad)
}

\author{
Somayyeh Beyki
}

Department of Architecture \& Urban Planning, Payame Noor University (PNU), I.R., Iran

Mohammad Shabani

Department of Architecture \& Urban Planning, Payame Noor University (PNU), I.R., Iran

Tayebeh Nazarian

Department of Architecture \& Urban Planning , Imam Khomeini International University, Qazvin, Iran

Nafise Rezaii

Department of Architecture \& Urban Planning , International Non-profit University of Imam Reza (AS), Mashhad, Iran

Hamid Fakhimzade

Department of Art and Architecture, Mashhad Branch, Islamic Azad University, Mashhad, Iran

Doi:10.5901/mjss.2016.v7n4s1p65

\begin{abstract}
Open, arid, unbuilt spaces by roadside, in neighborhoods and urban areas are of hidden urban areas that despite numerous potential, they are left unused. Due to lack of proper public sport places in the cities, by changing into open sports ground, these spaces can be a good opportunity to improve the quality of life, organization of urban spaces, neighborhood orientation, and development of public services and welfare. Although transforming the urban non-spaces into spaces to dynamic sports spaces has happened in some cities based on article 110 of the Municipal Act, the neglect of social and economic structure of consumer groups, non-functional hierarchy of sports grounds, lack of attention to the texture and the absence of clear standards and criteria to choose the kind of exercise in proportion to the size and orientation of user groups have reducing the productivity of the land. The aim of this study is to identify criteria to categorize temporary outdoor sports grounds and classify them according to the criteria extracted. The method of study is based on field research methods and techniques of hierarchical analysis, fuzzy logic models and integrating layers. The results of this research is to develop different standards in terms of social, economic, physical, environmental and management issues about grouping these lands to increase productivity and efficiency. The criteria are determined in terms of location analysis, evaluation and grouping of land.
\end{abstract}

Keywords: sports fields, criteria, location, evaluation, categorizing

\section{Introduction}

One of the most basic processes of human society has been the process of urbanization, which has increasingly been growing in the past century (Mirei et al, 2012: 104). Because of this growth and its dramatic effects, we witness lost spaces in the context of urban spaces. Defenseless spaces in the context of urban spaces, in addition to the destruction of the urban body and changing its landscape has resulted in unsafe areas within the urban fabric and the creation of social and cultural abnormalities.

In notion of sustainable development, human is considered as the core and the most important asset of any society is human capital (Hussaini, 2009: 4). Hence, development of social welfare, the environmental safety, improving the quality of life in urban areas and with the development of environmental agencies, improving urban management and so on, the issue of locating and organizing the cultural and urban services in the cities has experienced a qualitative change. The issue of how open land scattered in the neighborhoods and urban areas can be adapted to the social structure of nearby residents, the neighborhood and a variety of sports tailored to the texture, maximum performance and the use of 
potentials in order to raise quality of life and urban spaces is of cases in which special planning is required.

This article is analytical-applied and attitude is exploration-explanatory. The objective of the qualitative research is the quality of dealing and catagorizing the open lands within space. Therefore, regarding the goal, the study is developmental. According to the objectives of this study, 300 residents of Mashhad were surveyed on outdoor sports ground the purpose of which is to achieve better social reality and not to generalize the results. The unit of analysis in this study is "outdoor sport spaces" but the unit of observation has been "person (the respondents)." Thus, analysis level will be moderate.

Initial study (field study) means that data are collected that have not existed before. Initial research is usually done after the second study gave the researcher an overview on the issue. Methods of data collection in the study in studying environment is divided into three main categories including survey, focal points are observation.

In this regard, the current situation of open sports fields in terms of size, location, neighborhood, and type of access are separately evaluated and identified.

In the next step, Mashhad is studied in terms of socio-economic traits and the status of each land is evaluated in terms of socio-economic status. Then various measures have been introduced in the classification of land and land are grouped according to their socio-economic and physical status.

\section{Renewal of Hidden Urban Spaces}

Open spaces between residential buildings is the bond with nature and the place for spending leisure time in everyday life (Eini Far, Ghazizadeh., 2010: 36). Open space is a part of urban environment that by its facilities whether visually by having a positive impact on the urban landscape and through public access is effective (Mozafar et al., 92: 97-94). These spaces are a reflection of cultural values and helps create a sense of trust and confidence to people and increase the sense of solidarity and belonging in people (Carmona, 1391: 78-70).

Urban hidden spaces are opportunities that have been left without attention and despite the numerous potential no benefits and appropriate use of them is conceived and of course they do not help the city. Opportunities that especially due to lack of proper spaces for public sports in cities could be used more and compensate for this vacuum [1].

Moreover, urban open space is for citizens and their crystallization of collective life, and should meet needs of their social and collective life. In these spaces citizens have face-to-face social interactions with each other. The interlocuters of this space a wide range of social strata, different age groups, and so on [2].

Diversity and complete distribution of sports fields proportional to the social structure of neighboring residents increases authority and power and efficient use of the sports fields will be selected.

In other words, municipality has implemented very useful programs and measures in encouraging citizens to exercise and managing state-sanctioned sports. In this regard, the role of municipal management with a wide range of construction and service tasks in the field of developmental of sports facilities with the aim of providing spaces for spending leisure time of citizens is very important $[3,4]$.

Also stressing the importance of neighborhood in managing city and urban management due to the development of sport for citizens in urban areas creates a sense of belonging to the neighborhood and the city. In fact, development of sport spaces at local level sttengthens social mobility of the population living in urban areas and creates a healthy social connection and creates intimacy with the love and friendship, and sportsmanship [5].

\section{Understanding the Study Area}

Mashhad with a population of 2427000 people and an area of 29580 hectares is the second largest metropolis in the country. Mashhad city's population growth rate has been high in comparison with other metropolises and from1966-1977 so far has had the highest growth rate among other metropolises introduced [6]. Thus, the use of hidden urban spaces as the existing potential to provide services for this population growth can be an effective step.

Because social, cultural and economic characteristics of the people are effective in choices and tendency to spend leisure time sports, etc., social studies are done in different areas for social grouping.

From the data collected, three major social variables that have been more involved in determining lifestyle of the community have been the basis for comparison and classification of areas [8].

According to defined criteria and based on studies in Mashhad, five clusters that indicate socio-economic status from weak to optimum are shown in five different colors in Figure 1. 


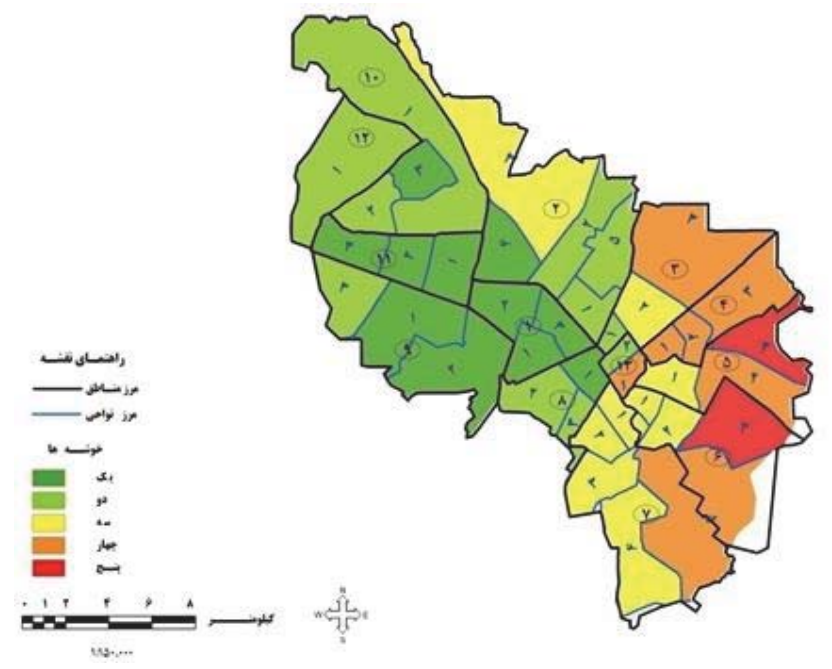

Figure 1: Socio-economic Zoning of Mashhad [9]

\section{Sports Fields and Socio-Economic Levels}

Identify the relationship between a variety of outdoor sports fields with diverse socio-economic levels in Mashhad is difficult, because open sports fields only have physical entity and do not have social human identity in themselves. Thus, for dividing lands into different proposed levels, consider the the following criteria:

1. The extent or size of the land: about one-third of the sample respondents used open sports land of 1000 meters and smaller and another one-third used between 1001 to 2000 meters (usually a total of $64.4 \%$, or about two-thirds of the total) and the remaining one-third of the respondents used larger lands. As the area of land is less the number of beneficiaries of its land is higher and vice versa.

2. Diverstity of each of outdoor sports facilities: diversity in sports facilities and activities causes increase in the population using it.

3. The number of spaces related to each sport in each of the land: this is a very effective in absorption of users.

Location of outdoor sport spaces such as access to it by local residents, security index, beauty and so on.

Area of most of the open sports spaces in Mashhad is small (below 2000 or even below $1000 \mathrm{~m}$ ). High cost of land in a great city like Mashhad does not let construction of a large number of big areas especially in central parts or middle and upper socio-economic grade places, so that in the sample studied $31.3 \%$ was lands below $1000 \mathrm{~m}$ and $33.3 \%$ to lands of 1000 to 2000 meters.

Although various regions and areas of the city have main differences in the enjoyment of facilities, in all of them the same sport is performed. According to a survey conducted in 13 districts in Mashhad, sports such as futsal, 35 percent, volleyball 23.3 percent, small goal football 18.4\%, Ping-Pong $12.1 \%$, basketball $9.7 \%$ and skating $1 \%$ have been played [10].

Therefore, performing the sports mentioned is not related to the level of the socio-economic level, but it is related to sport facilities on one hand and on the other hand to exercise habits of the citizens. However, in case of providing those sports that require more expensive equipment, it is likely that they are more welcomed by wealthy areas of Mashhad.

\section{The Criteria for Grouping Sports Fields}

On locating areas with important uses, different criteria in terms of social, economic, physical, environmental ones are used. Measures by using which in different models and analyzing them the best position dedicated to activities can be provided. In line with the performance of these activities, in addition to location, they should be evaluated regarding spatial positioning. 
In evaluation, positioned spaces are prioritized due to their nature, goals, structure, and physical space measured and locations of these activities. The evaluation criteria for programs of monitoring the situation and coordinating and match their overlapping goals in the period of time the program is used. Classification criteria are done in line with grouping according to the characteristics of the sports fields. Table (2) offers criteria to be applied in the space analysis, site selection, evaluation and sport uses.

Table 1: Description of the major factors affecting locating, evaluating and categorizing the sports fields [11]

\begin{tabular}{|c|c|c|c|c|c|}
\hline Type of analysis & Socio-demographic & Economic & Physical & Environmental & Management \\
\hline Positioning & $\begin{array}{l}\text {-Population } \\
\text {-The age - sex structure } \\
\text {-Level of education } \\
\text { - Cultural structure }\end{array}$ & $\begin{array}{l}\text {-The value of land } \\
\text { - Economic status of households } \\
\text { - The type of seizure } \\
\text { - The current activity }\end{array}$ & $\begin{array}{l}\text { Neighborliness } \\
\text {-Network access } \\
\text {-The extent and breadth of the } \\
\text { land } \\
\text {-Level / Performance Scale } \\
\text {-Details Date Location } \\
\text {-Access to infrastructure } \\
\text {-Type: } \\
\text { - nobility- privacy }\end{array}$ & $\begin{array}{l}\text {-Climatic } \\
\text { factors } \\
\text {-Soil } \\
\text {-Topography } \\
\text {-Orientation } \\
\text {-Species } \\
\text {-Sun } \\
\text { - Wind } \\
\text { - Rain }\end{array}$ & - Land ownership \\
\hline Evaluation & $\begin{array}{l}\text {-Population } \\
\text {-The number of visitors } \\
\text {-The time use of land } \\
\text {-Level of education } \\
\text {-Age } \\
\text {-Material } \\
\text {-The level of welfare of } \\
\text { citizens } \\
\text { - Sporting interests of } \\
\text { citizens }\end{array}$ & $\begin{array}{l}\text {-Per capita income } \\
\text {-Occupational prestige } \\
\text {-The value of ground movement } \\
\text { - Impact on the value of land and the } \\
\text { environment }\end{array}$ & $\begin{array}{l}\text {-Neighborliness } \\
\text {-Network of access } \\
\text {-The extent and breadth of the } \\
\text { land } \\
\text {-The land } \\
\text {-Level / Performance Scale } \\
\text {-Land position in the area / region } \\
\text { / city } \\
\text { - Land use mapping City } \\
\text {-Aristocracy-privacy } \\
\text { - The role of induction and } \\
\text { collective memory }\end{array}$ & \begin{tabular}{|l|}
-Slope \\
-The Sun \\
-Shading \\
- Wind direction \\
\end{tabular} & $\begin{array}{l}\text {-Maintenance of } \\
\text { land } \\
\text {-Land } \\
\text { management } \\
\text { - Social } \\
\text { participation }\end{array}$ \\
\hline $\begin{array}{l}\text { Land } \\
\text { classification }\end{array}$ & $\begin{array}{l}\text {-Population of district / } \\
\text { region / area } \\
\text {-The amount of visitors } \\
\text {-The use of land } \\
\text {-Level of education } \\
\text {-Age } \\
\text {-Material } \\
\text {-Ethnic neighborhoods } \\
\text {-Willingness to public } \\
\text { participation } \\
\text {-Social Security } \\
\text {-The level of welfare of } \\
\text { citizens } \\
\text { - Sporting interests of } \\
\text { citizens }\end{array}$ & $\begin{array}{l}\text {-Per capita income } \\
\text {-Occupational prestige } \\
\text { - The value of ground movement }\end{array}$ & $\begin{array}{l}\text {-Neighborliness } \\
\text {-Network of access } \\
\text {-The extent and breadth of the } \\
\text { land } \\
\text {-The Earth } \\
\text {-Level / Performance Scale } \\
\text {-Land position in the area / region } \\
\text { / city } \\
\text {-Physical standards of sports } \\
\text { - The role of induction and } \\
\text { collective memory }\end{array}$ & \begin{tabular}{|l|} 
Slope \\
-The Sun \\
-Shading \\
- Wind direction \\
\end{tabular} & $\begin{array}{l}\text {-Maintenance of } \\
\text { land } \\
\text {-Land } \\
\text { management } \\
\text { - Social } \\
\text { participation }\end{array}$ \\
\hline
\end{tabular}

Given that the purpose of this discussion is grouping the sports fields proportional to its physical condition, from among the classification criteria presented in the table above, criteria responsive to the target were selected are introduced:

- The number of visitors at peak hours: The purpose of this standard is to respond to maximum people referring to current exercise activities in the land devoted to these type of activities.

- The land shape (physical proportions of the land): The land shape should be consistent with the standard of sports with priority on the municipal division performance levels and respond to the requests of users along with observing the standards.

- The area of land

- Physical standards for a variety of sports: Standards have a close relationship with the sport with priority selected by the residents of the neighborhood priority and determine the type of sport and physical status of the land in question.

- Network of communication

- Neighborliness of land: By rating and determining the degree of importance for neighborliness criterion, one can reduce its negative effects on the sports ground. Avoiding proximity to residential areas and proximity to public uses such as education, green space, services, etc. are recommended. 


\section{The Application of the Criteria for Classification of Land}

The criteria used in the classification of the sports fields are huge qualitative and quantitative criteria that are in conformity with each other have the capability of grouping open sport land. Since Mashhad has heterogenious social and economic tissue, one cannot consider the same rank and weight for each criterion, these differences along with other criteria such as proximity, the capacity of the population, area, and access create complex conditions. To this end, and in line with the criterion of realism in the region, in categorizing, fuzzy analytical and hierarchical models are used.

In using fuzzy logic, at first the criteria are made homogenous and then according to the structure of each area and urban area, the criteria associated with the classification are weighed. Then, by combining them, a classification in small, medium and large categories is achieved that encompasses not only the land area but also other standard such as population capacity of each of the areas, adjacency of land, levels of performance, network of access, shape and size of the land. At this stage, the relationship between criteria and sub criteria is hierarchically defined. Then after the weighting criteria, in order to assimilate criteria and more realism in the work, fuzzy criteria are used and each criterion and their sub criteria are classified between 0 and 1 . Chart 1 shows how to make the hierarchy relevant to the subject and target.

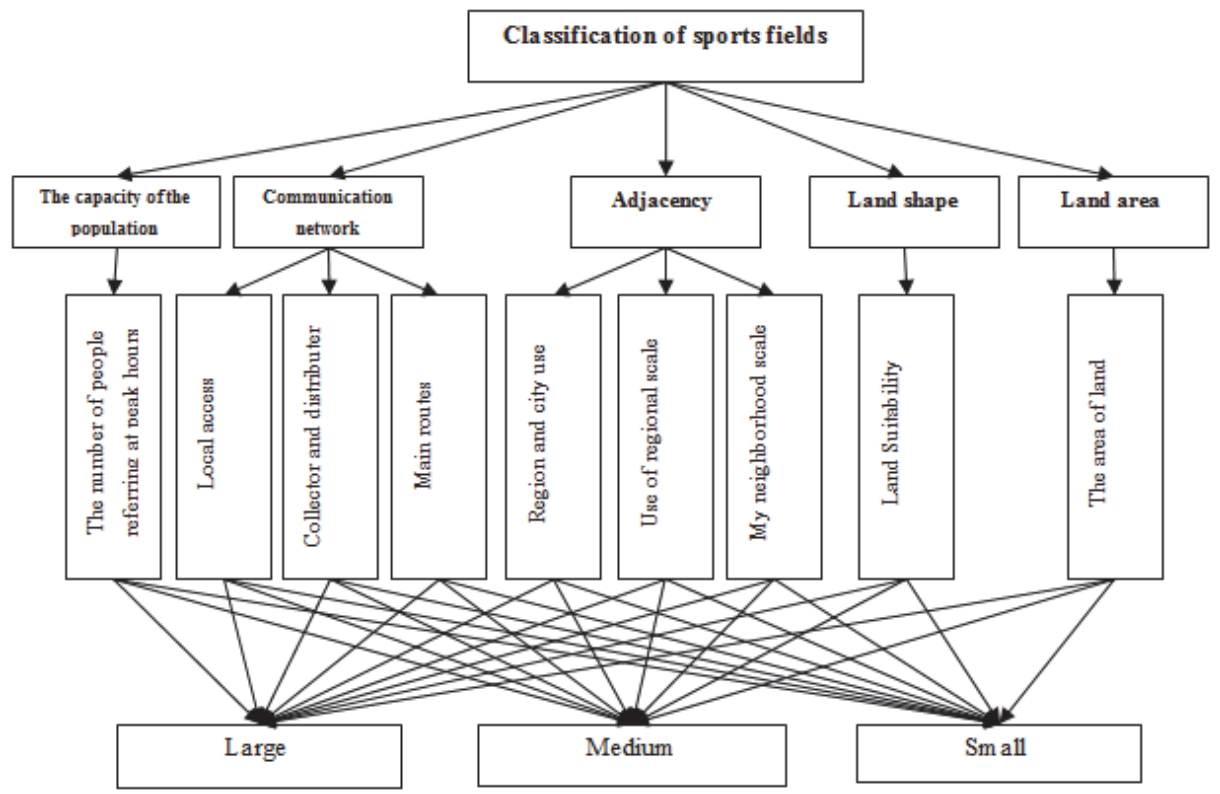

Figure 1: Hierarchy for classification for land

According to the weighting of the criteria in each area the lands are grouped. Thus, land in any area is classified regarding the type of sport, the situation in the region and its territories, the total weight of each criteria and finally classified to to large to small classes.

It should be noted that in classification of each land in categories of small to very large, in addition to the criteria of land area, various criteria in terms of proximity, communication network, shape and form of the landand and the number of people referring at hours peak are also considered. Thus, according to the standard weight in any urban area, lands with different areas may be placed in each small to large groups. This fact indicates that are criterion is not the only applicable criterion. 
Table 2: A model for establishing open sport land with area groups of ideal social structure [11]

\begin{tabular}{|c|c|c|c|c|c|}
\hline \multirow{2}{*}{ Area Grouping } & \multirow{2}{*}{$\begin{array}{l}\text { Qualitative indicators to determine the } \\
\text { (type of sport after 2010) }\end{array}$} & \multirow{2}{*}{\multicolumn{2}{|c|}{ Area }} & \multicolumn{2}{|c|}{ Prioritization of the proposed sports } \\
\hline & & & & Team sports & Individual sports \\
\hline \multirow{5}{*}{ Small } & \multirow{5}{*}{$\begin{array}{c}\text { Distance more than } 250 \text { meters from the } \\
\text { main road network and closeness to the } \\
\quad \text { local road network (access) } \\
\text { Proximity to local services are less than } \\
100 \text { meters (schools, green spaces, local } \\
\text { businesses, etc.) } \\
\text { The maximum people referred to in the } \\
\text { peak hours, less than } 20 \text { people }\end{array}$} & $\begin{array}{l}\text { Less than } 500 \\
\text { square meters }\end{array}$ & \begin{tabular}{|l|}
$100-200$ \\
$200-300$ \\
$300-400$ \\
$400-500$ \\
\end{tabular} & $\begin{array}{l}\text { Basketball } \\
\text { Volleyball } \\
\text { Mini handball }\end{array}$ & $\begin{array}{l}\text { Badminton } \\
\text { Table tennis } \\
\text { Chess }\end{array}$ \\
\hline & & & $500-600$ & Small goal & Tennis \\
\hline & & $\begin{array}{c}500 \text { to } 700 \text { square } \\
\text { meters }\end{array}$ & $600-700$ & $\begin{array}{l}\text { Basketball } \\
\text { Volleyball } \\
\text { Mini handball }\end{array}$ & $\begin{array}{l}\text { Badminton } \\
\text { Table tennis } \\
\text { Chess }\end{array}$ \\
\hline & & \multicolumn{2}{|c|}{700 to 800 square meters } & \multirow{2}{*}{$\begin{array}{l}\text { Futsal } \\
\text { Small goal } \\
\text { Basketball } \\
\text { Volleyball } \\
\text { Mini handball }\end{array}$} & $\begin{array}{c}\text { Tennis } \\
\text { Badminton } \\
\text { Table tennis } \\
\text { Chess }\end{array}$ \\
\hline & & \multicolumn{2}{|c|}{ More than 800 meters } & & $\begin{array}{c}\text { Skate } \\
\text { Tennis } \\
\text { Badminton } \\
\text { Table tennis } \\
\text { Chess } \\
\end{array}$ \\
\hline \multirow{3}{*}{ Medium } & \multirow{3}{*}{$\begin{array}{c}50 \text { to } 150 \text { meters distance from the main } \\
\text { road network (MAP) and the proximity of } \\
\text { the road network and players } \\
\text { Proximity to local services are less than } \\
100 \text { meters (schools, green spaces, } \\
\text { commercial areas, etc.) } \\
\text { The maximum people referred in the } \\
\text { peak hours between } 20 \text { and } 40\end{array}$} & \multicolumn{2}{|c|}{1000 square meters or less } & \multicolumn{2}{|c|}{$\begin{array}{l}\text { With small field sports proportional to } \\
\text { the area of land }\end{array}$} \\
\hline & & \multicolumn{2}{|c|}{100 to 1600 square meters } & $\begin{array}{l}\text { Small goal } \\
\text { Futsal }\end{array}$ & $\begin{array}{l}\text { Skate } \\
\text { Tennis } \\
\text { Badminton } \\
\text { Table tennis } \\
\text { Chess }\end{array}$ \\
\hline & & \multicolumn{2}{|c|}{$\begin{array}{l}1600 \text { square meters and } \\
\text { more }\end{array}$} & $\begin{array}{l}\text { Basketball } \\
\text { Volleyball } \\
\text { Mini handball }\end{array}$ & $\begin{array}{l}\text { Track and field } \\
\text { Skate } \\
\text { Tennis } \\
\text { Badminton } \\
\text { Table tennis } \\
\text { Chess }\end{array}$ \\
\hline \multirow{4}{*}{ Large } & \multirow{4}{*}{$\begin{array}{c}\text { Distance less than } 50 \text { meters from the } \\
\text { main road network (MAP) } \\
\text { Adjacent to the service area are less than } \\
100 \text { meters (schools, green spaces, } \\
\text { commercial areas, etc.) } \\
\text { The maximum people referred in the } \\
\text { peak hours between } 40 \text { to } 50\end{array}$} & \multicolumn{2}{|c|}{$\begin{array}{l}\text { Less than } 3,000 \text { square } \\
\text { meters }\end{array}$} & \multicolumn{2}{|c|}{ With medium and small sports fields } \\
\hline & & \multirow[b]{2}{*}{$\begin{array}{l}3000 \text { to } 4000 \\
\text { square meters }\end{array}$} & \begin{tabular}{|l|}
$3000-$ \\
3600
\end{tabular} & \multirow{2}{*}{$\begin{array}{c}\text { Futsal } \\
\text { Small goal } \\
\text { Basketball } \\
\text { Volleyball } \\
\text { Mini handball }\end{array}$} & $\begin{array}{l}\text { Track and field } \\
\text { Skate }\end{array}$ \\
\hline & & & $\begin{array}{l}3600- \\
3800\end{array}$ & & $\begin{array}{c}\text { Tennis } \\
\text { Badminton } \\
\text { Table tennis } \\
\text { Chess } \\
\end{array}$ \\
\hline & & \multicolumn{2}{|l|}{$4000-4800$} & $\begin{array}{c}\text { Futsal } \\
\text { Small goal } \\
\text { Basketball } \\
\text { Volleyball } \\
\text { Mini handball }\end{array}$ & $\begin{array}{l}\text { Track and field } \\
\text { Skate } \\
\text { Tennis } \\
\text { Badminton } \\
\text { Table tennis } \\
\text { Chess } \\
\end{array}$ \\
\hline
\end{tabular}


Table 3: Model of setting outdoor sport area with the average social groups [11]

\begin{tabular}{|c|c|c|c|c|c|}
\hline \multirow[t]{2}{*}{ Area Grouping } & \multirow{2}{*}{$\begin{array}{l}\text { Qualitative indicators to determine the } \\
\text { type of sport (after 2010) }\end{array}$} & \multirow{2}{*}{\multicolumn{2}{|c|}{ Area }} & \multicolumn{2}{|c|}{ Prioritization of the proposed sports } \\
\hline & & & & Team sports & Individual sports \\
\hline \multirow{8}{*}{ Small } & \multirow{8}{*}{$\begin{array}{l}\text { Distance more than } 250 \text { meters from the } \\
\text { main road network (MAP) and close to } \\
\text { (the local road network access) } \\
\text { Proximity to local services is less than } \\
100 \text { meters (schools, green spaces, } \\
\text { local businesses, etc.) } \\
\text { The maximum people referred to in the } \\
\text { peak hours, less than } 20 \text { people }\end{array}$} & \multirow{4}{*}{$\begin{array}{l}\text { Less than } 500 \\
\text { square meters }\end{array}$} & $\begin{array}{l}100- \\
200\end{array}$ & - & \multirow{3}{*}{$\begin{array}{c}\text { Basketball } \\
\text { Badminton } \\
\text { Table tennis } \\
\text { Chess }\end{array}$} \\
\hline & & & $\begin{array}{l}200- \\
300\end{array}$ & \multirow{2}{*}{ Volleyball } & \\
\hline & & & $\begin{array}{l}300- \\
400\end{array}$ & & \\
\hline & & & $\begin{array}{l}400- \\
500\end{array}$ & $\begin{array}{l}\text { Basketball } \\
\text { Volleyball }\end{array}$ & $\begin{array}{l}\text { Badminton } \\
\text { Table tennis } \\
\text { Chess }\end{array}$ \\
\hline & & \multirow[b]{2}{*}{$\begin{array}{c}500 \text { to } 700 \\
\text { square meters }\end{array}$} & $\begin{array}{l}500- \\
600\end{array}$ & $\begin{array}{l}\text { Basketball } \\
\text { Volleyball }\end{array}$ & \multirow{2}{*}{$\begin{array}{c}\text { Tennis } \\
\text { Badminton } \\
\text { Table tennis } \\
\text { Chess }\end{array}$} \\
\hline & & & $\begin{array}{l}600- \\
700\end{array}$ & $\begin{array}{l}\text { Small goal } \\
\text { Basketball } \\
\text { Volleyball }\end{array}$ & \\
\hline & & \multicolumn{2}{|c|}{$\begin{array}{l}700 \text { to } 800 \text { square } \\
\text { meters }\end{array}$} & \multirow{2}{*}{$\begin{array}{c}\text { Futsal } \\
\text { Small goal } \\
\text { Basketball } \\
\text { Volleyball }\end{array}$} & \multirow{2}{*}{$\begin{array}{c}\text { Skate } \\
\text { Tennis } \\
\text { Badminton } \\
\text { Table tennis } \\
\text { chess }\end{array}$} \\
\hline & & $\begin{array}{r}\text { More than } 800 \\
\text { meters }\end{array}$ & quare & & \\
\hline \multirow[b]{3}{*}{ Medium } & \multirow{3}{*}{$\begin{array}{l}\text { Distance } 50 \text { to } 150 \text { meters from the } \\
\text { main road network (MAP) and close to } \\
\text { (the local road network access) } \\
\text { Proximity to local services is less than } \\
100 \text { meters (schools, green spaces, } \\
\text { local businesses, etc.) } \\
\text { The maximum people referred to in the } \\
\text { peak hours, less than } 20 \text { to } 40 \text { people }\end{array}$} & \multicolumn{2}{|c|}{1000 meters and less } & \multicolumn{2}{|c|}{$\begin{array}{l}\text { With small field sports proportional to the } \\
\text { area of land }\end{array}$} \\
\hline & & \multicolumn{2}{|c|}{1000 to 1400 meters } & \multirow[b]{2}{*}{$\begin{array}{l}\text { Small goal } \\
\text { Futsal } \\
\text { Basketball } \\
\text { Volleyball }\end{array}$} & \multirow[b]{2}{*}{$\begin{array}{c}\text { Skate } \\
\text { Tennis } \\
\text { Badminton } \\
\text { Table tennis } \\
\text { chess }\end{array}$} \\
\hline & & \multicolumn{2}{|c|}{1400 meters and more } & & \\
\hline \multirow[b]{2}{*}{ Large land } & \multirow{2}{*}{$\begin{array}{l}\text { Distance less than } 50 \text { meters from the } \\
\text { main road network (MAP) and close to } \\
\text { (the local road network access) } \\
\text { Proximity to local services is less than } \\
100 \text { meters (schools, green spaces, } \\
\text { local businesses, etc.) } \\
\text { The maximum people referred to in the } \\
\text { peak hours, less than } 40 \text { to } 50 \text { people }\end{array}$} & \multicolumn{2}{|c|}{$\begin{array}{c}\text { Less than } 3000 \text { square } \\
\text { meters }\end{array}$} & \multicolumn{2}{|c|}{ With medium and small sports fields } \\
\hline & & \multicolumn{2}{|c|}{$\begin{array}{c}\text { More than } 3000 \text { square } \\
\text { meters }\end{array}$} & $\begin{array}{c}\text { Football on the ground } \\
\text { Small goal } \\
\text { Futsal } \\
\text { Basketball } \\
\text { Volleyball }\end{array}$ & $\begin{array}{c}\text { Skate } \\
\text { Tennis } \\
\text { Badminton } \\
\text { Table tennis } \\
\text { chess }\end{array}$ \\
\hline \multirow{4}{*}{$\begin{array}{l}\text { Very large } \\
\text { lands }\end{array}$} & \multirow{4}{*}{$\begin{array}{l}\text { The proximity of arteries } 1 \text { and } 2 \\
\text { Proximity to local services and the city } \\
\text { are less than } 100 \text { meters (schools, } \\
\text { green spaces, commercial district, } \\
\text { hospital and so on) } \\
\text { The maximum people referred to in the } \\
\text { peak hours more than } 50 \text { people }\end{array}$} & \multicolumn{2}{|c|}{$\begin{array}{l}\text { Less than } 5000 \text { square } \\
\text { meters }\end{array}$} & \multicolumn{2}{|c|}{$\begin{array}{c}\text { With medium, large and small sports land in } \\
\text { proportion to the land area }\end{array}$} \\
\hline & & \multicolumn{2}{|c|}{$\begin{array}{l}5000 \text { to } 6000 \text { square } \\
\text { meters }\end{array}$} & $\begin{array}{c}\text { Football on the ground } \\
\text { Handball } \\
\text { Small goal } \\
\text { Futsal } \\
\text { Basketball } \\
\text { Volleyball } \\
\end{array}$ & \multirow{3}{*}{$\begin{array}{l}\text { Skate } \\
\text { Tennis } \\
\text { Badminton } \\
\text { Table tennis } \\
\text { chess }\end{array}$} \\
\hline & & \multicolumn{2}{|c|}{$\begin{array}{l}6000 \text { to } 7000 \text { square } \\
\text { meters }\end{array}$} & $\begin{array}{c}\text { Football on the ground } \\
\text { Handball } \\
\text { Small goal } \\
\text { Futsal } \\
\text { Basketball } \\
\text { Volleyball }\end{array}$ & \\
\hline & & \multicolumn{2}{|c|}{$\begin{array}{c}\text { More than } 7000 \text { square } \\
\text { meters }\end{array}$} & $\begin{array}{c}\text { Football on the ground } \\
\text { Handball } \\
\text { Small goal } \\
\text { Futsal } \\
\text { Basketball } \\
\text { Volleyball }\end{array}$ & \\
\hline
\end{tabular}


Table 4: A model for the establishment of an outdoor sport area in groups with weak social structure [11]

\begin{tabular}{|c|c|c|c|c|c|}
\hline \multirow[t]{2}{*}{ Area Grouping } & \multirow{2}{*}{$\begin{array}{l}\text { Qualitative indicators to determine the } \\
\text { type of sport (after 2010) }\end{array}$} & \multirow{2}{*}{\multicolumn{2}{|c|}{ Area }} & \multicolumn{2}{|c|}{ Prioritization of the proposed sports } \\
\hline & & & & Team sports & \\
\hline \multirow{8}{*}{ Small } & \multirow{8}{*}{$\begin{array}{l}\text { Distance more than } 250 \text { meters from the } \\
\text { main road network (MAP) and close to } \\
\text { the local road network (access) } \\
\text { Proximity to local services is less than } \\
100 \text { meters (schools, green spaces, local } \\
\text { businesses, etc.) } \\
\text { The maximum people referred to in the } \\
\text { peak hours, less than } 20 \text { people }\end{array}$} & & $\begin{array}{l}100- \\
200\end{array}$ & - & \multirow{8}{*}{$\begin{array}{l}\text { Badminton } \\
\text { Table tennis } \\
\text { Chess }\end{array}$} \\
\hline & & Less than 500 & $\begin{array}{l}200- \\
300\end{array}$ & \multirow{2}{*}{ Volleyball } & \\
\hline & & square meters & $\begin{array}{l}300- \\
400\end{array}$ & & \\
\hline & & & $\begin{array}{l}400- \\
500\end{array}$ & \multirow{2}{*}{$\begin{array}{l}\text { Basketball } \\
\text { Volleyball }\end{array}$} & \\
\hline & & \multirow[b]{2}{*}{$\begin{array}{l}500 \text { to } 700 \\
\text { square meters }\end{array}$} & $\begin{array}{l}500- \\
600\end{array}$ & & \\
\hline & & & $\begin{array}{l}600- \\
700\end{array}$ & $\begin{array}{l}\text { Small goal } \\
\text { Basketball } \\
\text { Volleyball }\end{array}$ & \\
\hline & & \multicolumn{2}{|c|}{$\begin{array}{l}700 \text { to } 800 \text { square } \\
\text { meters }\end{array}$} & $\begin{array}{l}\text { Small goal } \\
\text { Futsal }\end{array}$ & \\
\hline & & \multicolumn{2}{|c|}{$\begin{array}{c}\text { More than } 800 \text { square } \\
\text { meters }\end{array}$} & $\begin{array}{l}\text { Basketball } \\
\text { Volleyball }\end{array}$ & \\
\hline \multirow[b]{2}{*}{ Medium } & \multirow{2}{*}{$\begin{array}{l}\text { Distance } 50 \text { to } 150 \text { meters from the main } \\
\text { road network (MAP) and close to the } \\
\text { local road network access)( } \\
\text { Proximity to local services is less than } \\
100 \text { meters (schools, green spaces, local } \\
\text { businesses, etc.) } \\
\text { The maximum people referred to in the } \\
\text { peak hours, less than } 20 \text { to } 40 \text { people }\end{array}$} & \multicolumn{2}{|c|}{1000 meters and more } & \multicolumn{2}{|c|}{$\begin{array}{l}\text { With small field sports proportional to the } \\
\text { area of land }\end{array}$} \\
\hline & & \multicolumn{2}{|c|}{1000 meters and more } & $\begin{array}{l}\text { Small goal } \\
\text { Futsal } \\
\text { Basketball } \\
\text { Volleyball }\end{array}$ & $\begin{array}{l}\text { Badminton } \\
\text { Table tennis } \\
\text { Chess }\end{array}$ \\
\hline \multirow[b]{2}{*}{ Large land } & \multirow{2}{*}{$\begin{array}{l}\text { Distance less than } 50 \text { meters from the } \\
\text { main road network (MAP) and close to } \\
\text { the local road network access)( } \\
\text { Proximity to local services is less than } \\
100 \text { meters (schools, green spaces, local } \\
\text { businesses, etc.) } \\
\text { The maximum people referred to in the } \\
\text { peak hours, less than } 40 \text { to } 50 \text { people }\end{array}$} & \multicolumn{2}{|c|}{$\begin{array}{c}\text { Less than } 3000 \text { square } \\
\text { meters }\end{array}$} & \multicolumn{2}{|c|}{ With medium and small sports fields } \\
\hline & & \multicolumn{2}{|c|}{$\begin{array}{c}\text { More than } 3000 \text { square } \\
\text { meters }\end{array}$} & $\begin{array}{c}\text { Football on the ground } \\
\text { Small goal } \\
\text { Futsal } \\
\text { Basketball } \\
\text { Volleyball }\end{array}$ & $\begin{array}{l}\text { Badminton } \\
\text { Table tennis } \\
\text { Chess }\end{array}$ \\
\hline \multirow{4}{*}{ Very large land } & \multirow{4}{*}{$\begin{array}{l}\text { The proximity of arteries } 1 \text { and } 2 \\
\text { Proximity to local services and the city } \\
\text { are less than } 100 \text { meters (schools, green } \\
\text { spaces, commercial district, hospital and } \\
\text { so on) } \\
\text { The maximum people referred to in the } \\
\text { peak hours more than } 50 \text { people }\end{array}$} & \multicolumn{2}{|c|}{$\begin{array}{c}\text { Less than } 5000 \text { square } \\
\text { meters }\end{array}$} & \multicolumn{2}{|c|}{$\begin{array}{l}\text { With medium, large and small sports land } \\
\text { in proportion to the land area }\end{array}$} \\
\hline & & \multirow[b]{2}{*}{$\begin{array}{l}5000 \text { to } 7000 \\
\text { square meters }\end{array}$} & $\begin{array}{l}5000- \\
6500\end{array}$ & $\begin{array}{c}\text { Football on the ground } \\
\text { Small goal } \\
\text { Futsal } \\
\text { Basketball } \\
\text { Volleyball } \\
\end{array}$ & \multirow{3}{*}{$\begin{array}{l}\text { Badminton } \\
\text { Table tennis } \\
\text { Chess }\end{array}$} \\
\hline & & & $\begin{array}{l}6500- \\
7000\end{array}$ & $\begin{array}{c}\text { Football on the ground } \\
\text { Football } \\
\text { Small goal } \\
\text { Futsal } \\
\text { Basketball } \\
\text { Volleyball } \\
\end{array}$ & \\
\hline & & \multicolumn{2}{|c|}{$\begin{array}{c}\text { More than } 7000 \text { square } \\
\text { meters }\end{array}$} & $\begin{array}{c}\text { Football on the ground } \\
\text { Football } \\
\text { Small goal } \\
\text { Futsal } \\
\text { Basketball } \\
\text { Volleyball } \\
\end{array}$ & \\
\hline
\end{tabular}




\section{Conclusions}

To transform urban non-place spaces to dynamic places and exploitation of these spaces into spaces with temporary sports, the physical land, social and economic characteristics of the land and residents need from the complex and so on should be examined and the proposed final sports resulting from the integration of socio-economic criteria and physical criteria for classification of land should be offered.

In this regard, the areas should be divided and grouped into social and economic areas in three categories: good, moderate, and weak by criteria such as land area, land shape, the neighborhood, communication network and the population capacity and accordingly, the type of team and individual sports and performance measures should be determined, so that using the tables provided for each of the land according to the social structure the following can be revealed:

- Placement of land in each of the categories of small, medium, large or very large

- Indicators of the quality required according to the grouping of peripheral arteries, proximity to local, district, regional or municipal, the maximum amount referred to in peak time

- Area classification of the land

- The priority of the proposed sports as individual and team respectively

\section{References}

Mahzab Tollab, M. The role of sport in retrieving hidden urban spaces (spaces waiting), the First National Conference of Sports, Tehran, 2006.

Ghasemi, M. Urban plaza, courtyards urban city life, municipalities, Number 67, December 2004.

Saeednia, A. Urban management, publications municipalities, 2000.

Rahnamayi, M. Aghayi, L. The role of municipalities in the development of sport for citizens' leisure spaces (the case of the 6th district of Tehran), geography, number 22, autumn 2009.

Shia, A. Attitude to sport from the perspective of urban planning, the First National Conference of Sports, Tehran, 2006.

Faranhad consulting engineers, design development metropolis of Mashhad, human-based studies and activities, socio - cultural, 2009.

Article 110 of the municipal executive, Department of Planning and Architecture, 2003.

Yousefi, A. Reflection on the social division of urban space Mashhad Ferdowsi University of Mashhad, 2009.

Yousefi, Ali. Studies caste - standing areas of Mashhad, Mashhad Municipality, Department of Cultural - social, 2009.

Consulting engineers design and research iPod, studies the physical conditions of the sports fields open in Mashhad, 2010.

Consulting engineers design and research iPod, studies the physical conditions of the sports fields open in Mashhad, 2010.

Hussaini, H, components appropriate urban spaces from the perspective of physical-motor disabilities. Mashhad, Razavi Khorasan Welfare Research, 2009.

Einifar, A. Ghazizadeh, S.N, Tehran typology of residential complexes with outdoor criterion, publication of Utopia, No. 5, 2010.

Kaplan, D; Wheeler, Hmymza; Holloway, Steven R., urban geography. Abdul Hossein Hatami race and you need translation. Tehran: publishing side, 2012.

Carmona, Matthew, Heath, team, Tysvl, Steven, urban public places - different aspects of urban design: A charming recitations and Mahshid Shakuie and Z Ahari and Esmail Salehi. Tehran: Tehran Art University Press, 2012.

Mozafar, Farhang, Feizi, M, Asadpour, A, contemporary approaches to environmental research, urban open spaces, Environmental Logistics Quarterly, No. 21, 2013.

Mirei, Mohammad Hataminejad, Hussein. Fadaei, Z. Informal settlements in the world and Iran. Tehran: University Publication, 2012. 